\title{
Potential Effect of Porosity Evolution of Cemented Paste Backfill on Selective Solidification of Heavy Metal Ions
}

\author{
Yixuan Yang ${ }^{1}$, Tongqian Zhao ${ }^{1}$, Huazhe Jiao ${ }^{2, *}$, Yunfei Wang ${ }^{2}$ and Haiyan $\mathrm{Li}^{3}$ \\ 1 Institute of Resources and Environment, Henan Polytechnic University, Jiaozuo 454000, China; \\ yangyixuan@hpu.edu.cn (Y.Y.); zhaotq@hpu.edu.cn (T.Z.) \\ 2 International Joint Research Laboratory of Henan Province for Underground Space Development and \\ Disaster Prevention, School of Civil Engineering, Henan Polytechnic University, Jiaozuo 454003, China; \\ wyf_ustb@126.com \\ 3 School of Materials Science and Engineering, Henan Polytechnic University, Jiaozuo 454003, China; \\ lihaiyan@hpu.edu.cn \\ * Correspondence: jiaohuazhe@126.com
}

Received: 3 December 2019; Accepted: 20 January 2020; Published: 28 January 2020

\begin{abstract}
Cemented paste backfill (CPB) is a common environmentally friendly mining approach. However, it remains undetermined whether $\mathrm{CPB}$ pollutes underground mine water. Tank leaching analysis of a CPB mass in distilled water was performed for $120 \mathrm{~d}$, and water quality was tested in situ for a long-term pollution assessment. Computerized tomography was also used to determine the CPB micro-pore structure and ion-leaching mechanism. The dissolved $\mathrm{Zn}^{2+}, \mathrm{Pb}^{2+}$ and $\mathrm{As}^{5+}$ concentrations in the leachate peaked at $0.56,0.11$ and $0.066 \mathrm{mg} / \mathrm{L}$, respectively, whereas the $\mathrm{Co}^{2+}$ and $\mathrm{Cd}^{2+}$ concentrations were lower than the detection limit. The CPB porosity decreased from $46.07 \%$ to $40.88 \%$ by soaking, and $80 \%$ of the pore diameters were less than $13.81 \mu \mathrm{m}$. The permeability decreased from 0.8 to $0.5 \mathrm{~cm} / \mathrm{s}$, and the quantity, length, and diameter of the permeate channels decreased with soaking. An in-situ survey showed novel selective solidification. The $\mathrm{Zn}^{2+}$ concentration in the mine water was 10-20 times that of the background water, and the $\mathrm{Pb}^{2+}$ concentration was $2-4$ times the regulated value. Although the $\mathrm{Pb}^{2+}$ content decreased significantly with mining depth, there remains a serious environmental risk. Mine water pollution can be reduced by adding a solidifying agent for $\mathrm{Pb}^{2+}$ and $\mathrm{Zn}^{2+}$, during CPB preparation.
\end{abstract}

Keywords: cemented paste backfill; tailings management; underground water pollution; heavy metal ions; selective solidification

\section{Introduction}

Massive volumes of tailings and wastewater are generated into the environment during mining and mineral processing [1,2]. There is a risk of tailings causing dam failure, depending on the method used for dam construction [3,4]. On 26 January, 2019, a serious dam failure accident led to over 300 people being killed or missing, in a Vale S.A. mine in Minas Gerais, Brazil [5]. Furthermore, the filtrate and runoff from tailing ponds contain numerous heavy metal ions and toxicants, and these create a significant issue with regard to the environment and human health [6,7]. The concentration of metals and acids in water close to mines and mine wastes, is significantly high [8,9].

The cemented paste backfill (CPB) approach is a high-efficiency method for solving the environmental and geological challenges induced by transporting tailings underground [10-12]. CPB has been widely used in tailing recycling [13,14], underground stope supporting [15] and open pit stabilising $[16,17]$. However, tailing particles and processing water contain numerous types of heavy 
metals. Most heavy metal ions can be recovered via thickening the water that is recycling back to the processing plant, but some are still delivered underground in the CPB mass [18]. Initially, in the thickener, a portion of the heavy metal ions and flotation reagents adsorbs to the flocculants [19], which combine with the tailing particles to form large aggregates. These aggregates settle to the bottom of thickener. The discharged thickener underflow is then pumped underground as $\mathrm{CPB}$ material. Second, the toxicants in the CPB material are fixed in the concreted mass underground, thereby avoiding or reducing diffusion [20]. The concreted CPB mass is a porous material, with cracks and pores [21-23].

Heavy metal solidification and leaching from cement-based materials have gained significant research attention $[24,25]$. In terms of solidification, $\mathrm{Cu}$ and $\mathrm{Pb}$ are predominantly absorbed by calcium silicate hydrate gels $(\mathrm{C}-\mathrm{S}-\mathrm{H})$, while $\mathrm{Cd}^{2+}, \mathrm{Ni}^{2+}$ and $\mathrm{Zn}^{2+}$ mainly precipitate as hydroxides within the intergranular pores [26]. The mobility of heavy metals in the Solidification/Stabilization system (S/S system), follows the order of $\mathrm{Cd}^{2+}>\mathrm{Pb}^{2+}>\mathrm{Zn}^{2+}>\mathrm{Cu}^{2+}>\mathrm{Ni}^{2+}$ [27]. Geopolymers have shown a high degree of solidification of $\mathrm{Pb}^{2+}, \mathrm{Cd}^{2+}, \mathrm{Mn}^{2+}$ and $\mathrm{Cr}^{6+}$ in fly ash $[13,28]$. The ionic radius $\mathrm{of}^{2+}$ is only approximately $13 \%$ larger than that of $\mathrm{Ca}^{2+}$, therefore, some authors have suggested replacing $\mathrm{Ca}^{2+}$ with $\mathrm{Pb}^{2+}[11]$.

In terms of leaching, the effectiveness in reducing the leachability of $\mathrm{Ba}^{2+}, \mathrm{Cd}^{2+}, \mathrm{Cu}^{2+}, \mathrm{Ni}^{2+}$ and $\mathrm{Pb}^{2+}$ was shown to be easy for natural zeolite-blended cement pastes [29]. Metals in cement were shown to be leachable in various media, in the descending order of $\mathrm{Cu}^{2+}, \mathrm{Cd}^{2+}, \mathrm{Pb}^{2+}, \mathrm{Zn}^{2+}, \mathrm{Mn}^{2+}$ and $\mathrm{Sb}^{3}$, but were not leached in simulated seawater, groundwater or acid rain [30]. The microstructure of cementation wastes containing $\mathrm{Pb}^{2+}, \mathrm{Cd}^{2+}, \mathrm{As}^{5+}$ and $\mathrm{Cr}^{6+}$ has been investigated [9,31,32]. Metal leaching in the pH range of 6-8, was shown to decrease in the following order: $\mathrm{Cr}^{6+}>\mathrm{Cd}^{2+}>\mathrm{Pb}^{2+}>\mathrm{As}^{5+}[9,33]$. High concentrations of $\mathrm{Zn}^{2+}$ and $\mathrm{Ni}^{2+}$ were observed in water and sediment soils, in streams located near the Chambishi copper mine in Zambia [32], however, no studies have yet determined whether $\mathrm{CPB}$ causes long-term pollution to underground water.

The structure of the present study was as follows: First, in a period of months (short term), the solidification effect of the CPB mass for specific metal ions was evaluated by a 120-day indoor soaking test. Second, over a period of years (long-term), the quality of the underground mine water was investigated, in terms of long-term solidification. Third, the physicochemical adsorption and leaching seepage mechanics were explained, via a leaching-out assessment. The influence of the real pore structure and fractures of the $\mathrm{CPB}$ mass on permeability, was studied by computed tomography (CT), nuclear magnetic resonance (NMR) and visual analysis. Finally, the question of whether the CPB mass pollutes underground mine water, was answered.

\section{Materials and Methods}

\subsection{Short-Term Leaching Test}

The EA NEN 2004 tank test [33] (Figure 1) was adopted to assess the leaching characteristics of metal ions from porous monoliths, which involved the leaching of cement mortar specimens, with distilled water as the leachate. The leachates were tested at six specific periods $(10,30,50,70,90$ and $120 \mathrm{~d}$ ). The CPB blocks were prepared with a copper mine tailing and Portland cement, and the tailings-to-cement ratio was 12:1 by weight, the same as the underground CPB. The block size was $70.7 \mathrm{~mm} \times 70.7 \mathrm{~mm} \times 70.7 \mathrm{~mm}$. The leachates were detected by a water quality heavy metal analyzer, to determine to ion concentration, as shown in Figure $1 \mathrm{~d}$. 


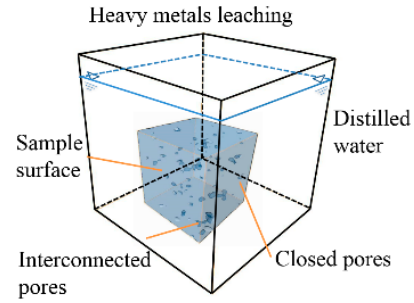

(a)

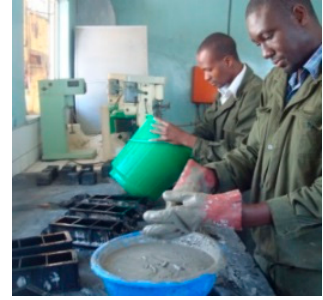

(b)

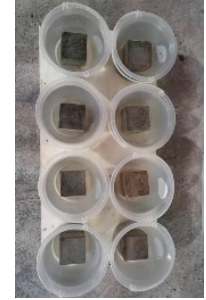

(c)

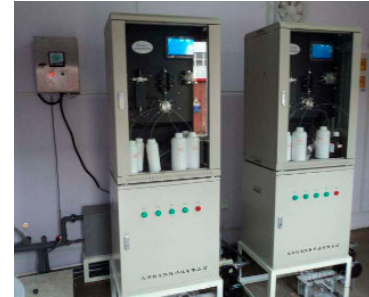

(d)

Figure 1. Cemented paste backfill (CPB) block leaching and leachate ion testing. (a) EA NEN 2004 tank test scheme. (b) CPB block preparation. (c) Blocks leaching. (d) Water quality heavy metal analyzer.

\subsection{Long-Term Solidification Performance Evaluation}

Underground mine water was sampled to evaluate leaching over years, as a long-term period. The CPB operation was established in 2013, in the Chambishi copper mine in Zambia, as shown in Figure 2. The tailing slurry was treated with a deep cone thickener, to output a high-concentration underflow; the paste underflow was then mixed with cement and transported underground through a pipeline, as shown in Figure 2c. The cement-sand ratio was 1:12 to 1:30, and the target uniaxial compressive strength (UCS) was $0.3-0.5 \mathrm{MPa}$. The CPB mass has been soaking in the mine water more than 6 years.

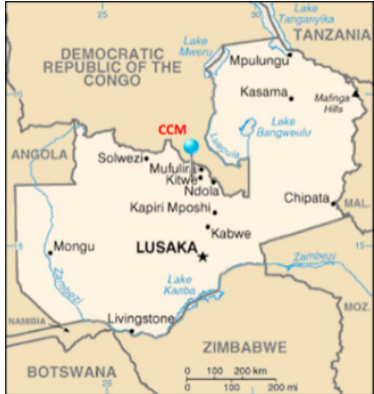

(a)

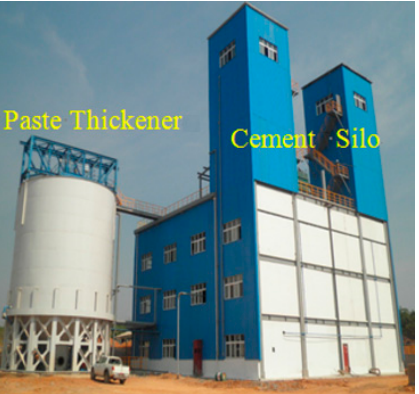

(b)

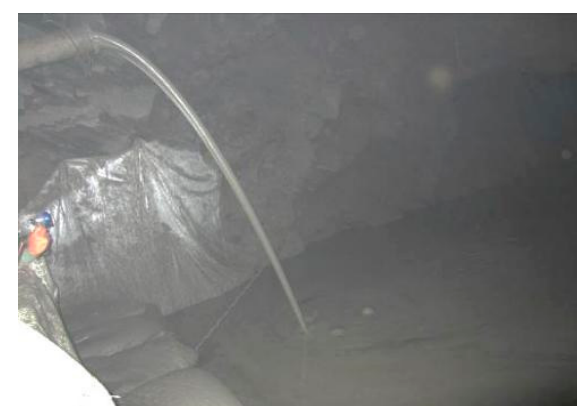

(c)

Figure 2. (a) Location of the Chambishi copper mine. Photographs of the (b) CPB plant and (c) underground stope backfill.

As shown in Figure 3, the underground mine water was sampled at 3 locations: $-116,-200$, and $-264 \mathrm{~m}$. It must be noted that the water was sampled directly from the roof, and the samples were not mixed with the mining treatment water.

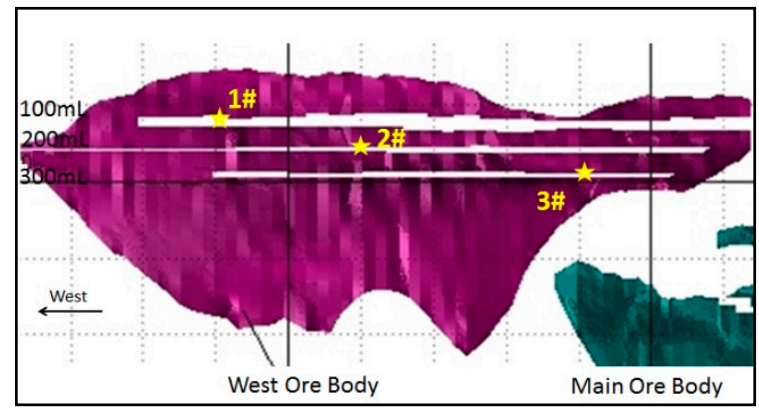

(a)

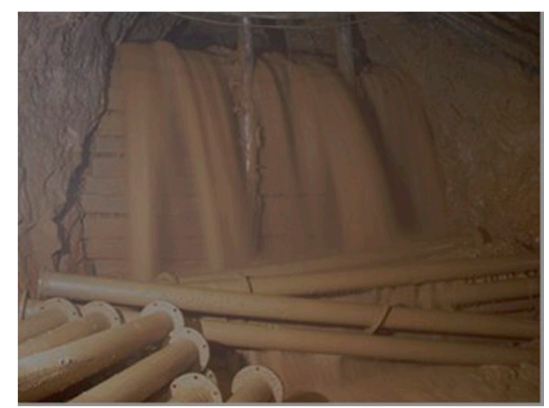

(b)

Figure 3. (a) Underground mine water sampling locations. (b) Photograph of the mine water from the roof. 


\subsection{Permeability and Porosity of the $C P B$}

The control CPB samples were tested to determine the permeability performance in the same period as indicated above. To determine the CPB porosity, the water in the pores was analyzed by NMR spectroscopy. A high-precision industrial micro-CT scanning system was adopted for porosity and pore visualization $[34,35]$. The reconstructed pore models were analyzed, to explain the heavy metal ion leaching process, as shown in Figures 4 and 5.

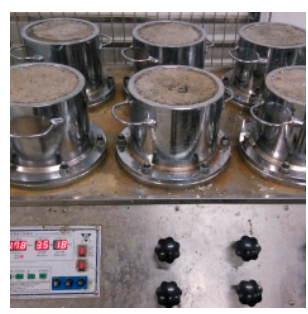

(a)

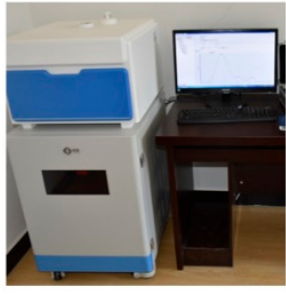

(b)

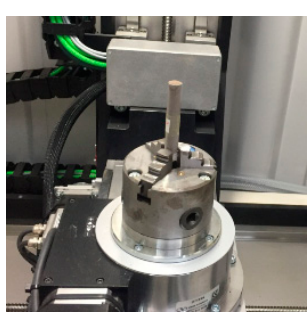

(c)

Figure 4. CPB block permeability and porosity testing. Equipment for (a) permeability, (b) NMR, and (c) CT analyses.

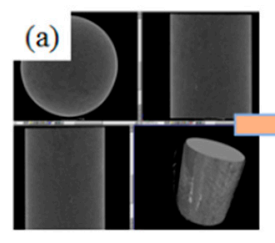

(h)

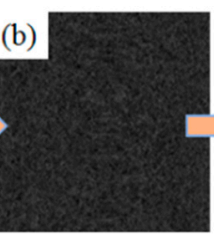

(g)

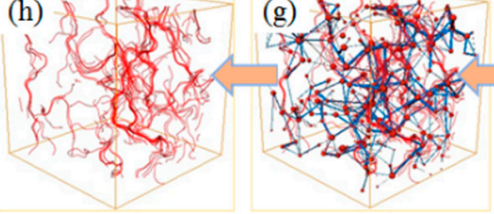

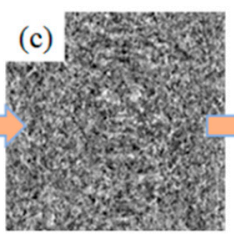

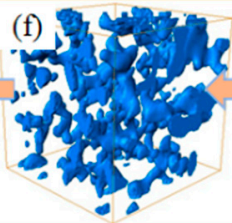

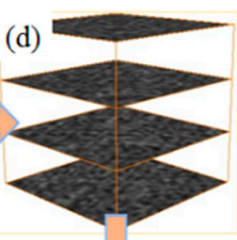

(e)

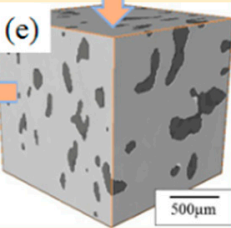

Figure 5. CPB block three-dimensional reconstruction and seepage simulation. (a) CT result, (b) CT image, (c) binary image, (d) images reconstruction, (e) 3D reconstruction model, (f) pore recognition, (g) pore network model, (h) pore seepage simulation.

\subsection{Tailings}

The contents of five toxicant heavy metal ions in the tailings used in this study, are shown in Table 1. The main ion is $\mathrm{Co}^{2+}$, with a content of $390.26 \mathrm{mg} / \mathrm{kg}$. The contents of the other 4 metals, $\mathrm{Zn}^{2+}$, $\mathrm{As}^{5+}, \mathrm{Cd}^{2+}$ and $\mathrm{Pb}^{2+}$, were approximately $70 \mathrm{mg} / \mathrm{kg}$.

Table 1. The contents of the main toxicant heavy metals in the tailings (units: $\mathrm{mg} / \mathrm{kg}$ ).

\begin{tabular}{cccccc}
\hline Component & $\mathbf{C o}^{2+}$ & $\mathbf{Z n}^{2+}$ & $\mathbf{P b}^{2+}$ & $\mathbf{A s}^{5+}$ & $\mathbf{C d}^{2+}$ \\
\hline Content & 390.26 & 68.30 & 72.31 & 70.70 & 69.63 \\
\hline
\end{tabular}

\section{Results and Discussion}

\subsection{Ion Leaching from the CPB in the Short-Term}

The ion concentrations in the leachate of $\mathrm{Co}^{2+}, \mathrm{Zn}^{2+}, \mathrm{Pb}^{2+}, \mathrm{As}^{5+}$ and $\mathrm{Cd}^{2+}$ are discussed in this section. The $\mathrm{Co}^{2+}$ and $\mathrm{Cd}^{2+}$ concentrations were lower than the detection limit. 


\subsubsection{Dissolved $\mathrm{Zn}^{2+}$ in Leachate}

The $\mathrm{Zn}^{2+}$ content was higher than that of the other metals in the leachate, as shown in Figure 6. The content increased from 0.05 to $0.56 \mathrm{mg} / \mathrm{L}$ during the first $70 \mathrm{~d}$, indicating that the $\mathrm{Zn}^{2+}$ sealed in the CPB blocks, had diffused into the water. In the following 70-120 d, the value decreased to $0.49 \mathrm{mg} / \mathrm{L}$, demonstrating that the dissolved ions in the water were re-adsorbed into the CPB blocks, after a critical soaking period.

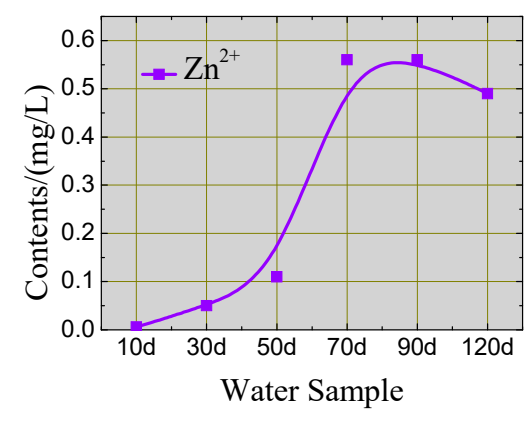

(a)

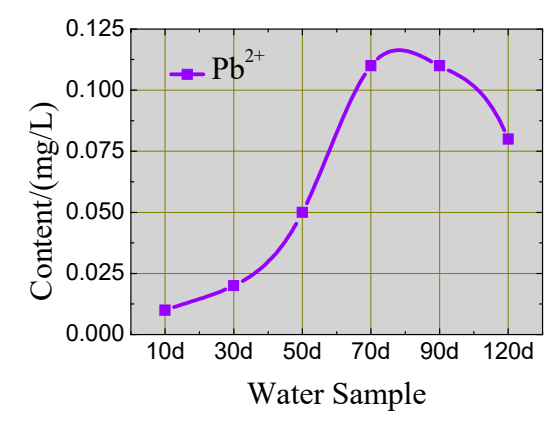

(b)

Figure 6. Dissolved (a) $\mathrm{Zn}^{2+}$ and (b) $\mathrm{Pb}^{2+}$ concentrations in the leachate.

$\mathrm{Zn}^{2+}$ ions will react with $\mathrm{OH}^{-}$to generate an amorphous granular layer of $\mathrm{Zn}(\mathrm{OH})_{2}$, that can attach to the surface of hydrated cement particles. The amorphous granular material is a mixture of zinc silicate gel and poorly crystallised C-S-H gel, that is unstable, and readily releases zinc ions during leaching - the adsorption is unstable and reversible, which is the reason for the increased dissolved $\mathrm{Zn}^{2+}$ concentration. In contrast, in the cement hydration process, $\mathrm{Zn}^{2+}$ will partially substitute and react with $\mathrm{Ca}^{2+}$ in the $\mathrm{C}-\mathrm{S}-\mathrm{H}$ gel to form $\mathrm{Ca}\left[\mathrm{Zn}(\mathrm{OH})_{3} \cdot \mathrm{H}_{2} \mathrm{O}\right]_{3}$, a crystalline hydrate of calcium and zinc. The reaction product is chemically stable, and thus the $\mathrm{Zn}^{2+}$ ions cannot be released from the crystal structure. This explains the lower concentration in the leachate than the original value in the tailings.

\subsubsection{Dissolved $\mathrm{Pb}^{2+}$ in Leachate}

As shown in Figure 7, the $\mathrm{Pb}^{2+}$ content was lower than that of $\mathrm{Zn}^{2+}$ in the first 70 days, increased from 0.02 to $0.11 \mathrm{mg} / \mathrm{L}$, then decreased to $0.08 \mathrm{mg} / \mathrm{L}$ after 120 days. These drops were caused by the re-adsorption of the $\mathrm{CPB}$. The main cement hydration products of the $\mathrm{CPB}$ were $\mathrm{C}-\mathrm{S}-\mathrm{H}$ gel, $\mathrm{Ca}(\mathrm{OH})_{2}$, $A F t$, and AFm. Among these, $\mathrm{C}-\mathrm{S}-\mathrm{H}$ gel has an extremely high specific energy and ion exchange capacity; ions can be fixed by adsorption, symbiosis and interlayer position replacement, etc. Ettringite can seal several kinds of ions in its crystal columns and channels by chemical substitution.

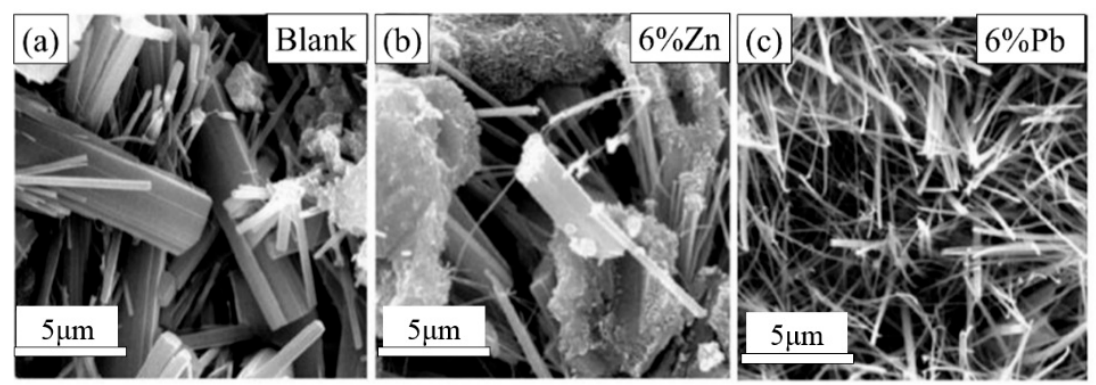

Figure 7. Change in shape of $\mathrm{C}-\mathrm{S}-\mathrm{H}$ induced by $\mathrm{Zn}^{2+}$ and $\mathrm{Pb}^{2+}$.

$\mathrm{Pb}^{2+}$ can replace $\mathrm{Ca}^{2+}$ in the $\mathrm{C}-\mathrm{S}-\mathrm{H}$ gel, by entering the $\mathrm{C}-\mathrm{S}-\mathrm{H}$ gel structure and bonding with $\mathrm{Ca}^{2+}$ and $\mathrm{Si}^{4+} . \mathrm{Pb}^{2+}$ changes the C-S-H gel density and nanostructure [22], and a large number of 
acicular crystals increase the porosity of the $\mathrm{CPB}$ mass. This contributes to the infiltration and physical adsorption of $\mathrm{Pb}^{2+}$ ions, however, the structural change also increases the crack and fracture quantity and width, as well as the loose material. This physical adsorption can be defined as weak in strength. The fractures create seepage flow-channels in the CPB mass that increase the contact between adsorbed ions and the leaching solution. Consequently, previous studies $[3,28]$ have shown that cement can solidify $\mathrm{Pb}^{2+}$ ions, and the solidification effect of the $\mathrm{CPB}$ mass on $\mathrm{Pb}^{2+}$ is lower than expected.

\subsubsection{Dissolved $\mathrm{Cd}^{2+}$ in Leachate}

The electric potential of $\mathrm{Cd}^{2+}$ is similar to that of $\mathrm{Ca}^{2+}$, as the difference in their ionic radii is less than $15 \%$, therefore, $\mathrm{Cd}^{2+}$ can replace $\mathrm{Ca}^{2+}$ in the cement hydration product. The replacement process forms the corresponding $\mathrm{Cd}$ silicate crystal gel, but the hydration product structure does not undergo a crystal lattice distortion. $\mathrm{Cd}^{2+}$ is captured by the $\mathrm{C}-\mathrm{S}-\mathrm{H}$ in two ways: the amorphous hydrated calcium silicate formed in the precipitation method, and ion exchange with the C-S-H [25]. After ion exchange, approximately $30 \%$ of $\mathrm{Cd}^{2+}$ can adsorb into the C-S-H in both free and solidified forms. The captured $\mathrm{Cd}^{2+}$ could originate not only from enrichment of co-precipitation, but also as a hydration product of both combinations, as shown in Figure 8. Rather than physical adsorption, chemical consolidation played a major role in the $\mathrm{Cd}^{2+}$ solidification mechanism.

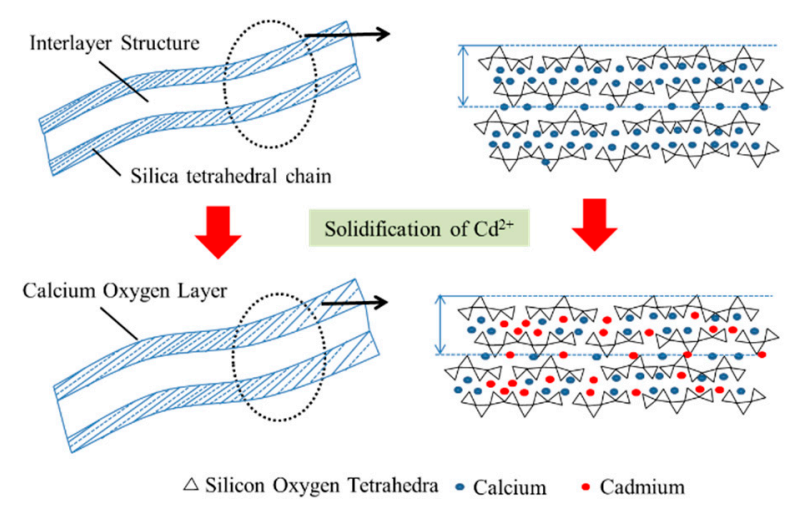

Figure 8. Impact of $\mathrm{Cd}^{2+}$ on the C-S-H gel structure.

3.1.4. Dissolved $\mathrm{As}^{5+}$ and $\mathrm{Co}^{2+}$ in Leachate

As shown in Figure 9a, the ions in the CPB blocks diffused into the leachate. The $\mathrm{As}^{5+}$ concentration increased from 0.053 to $0.066 \mathrm{mg} / \mathrm{L}$ after $30 \mathrm{~d}$ of soaking. Beyond $30 \mathrm{~d}$, the concentration curve decreased rapidly, owing to the re-adsorption process.

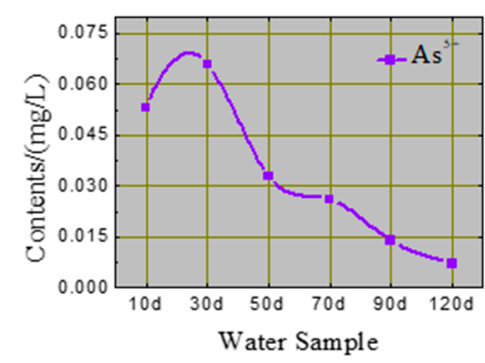

(a)

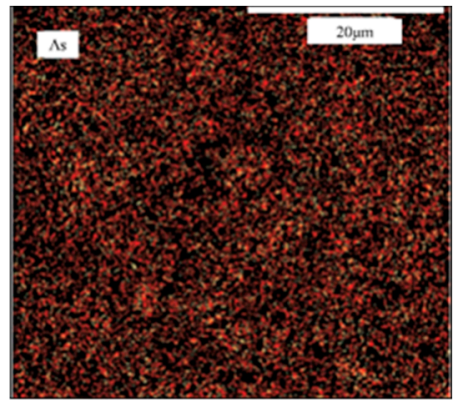

(b)

Figure 9. (a) $\mathrm{As}^{5+}$ concentration in leachate and (b) corresponding micro-morphology, determined by $\mathrm{X}$-ray imaging. 
The C-S-H gel is a layered silicate, and thus $\mathrm{As}^{5+}$ more readily consolidates in an ettringite lattice structure. The majority of the captured $\mathrm{As}^{5+}$ forms arsenate [28] that physically attaches or adsorbs onto the surface of the hydration product, as shown in Figure 9b.

The content of $\mathrm{Co}^{2+}$ in the leachate was extremely low. The particle surface bond energy is reduced by the destruction of $\mathrm{Ca}-\mathrm{O}$ bonds during cement grinding. $\mathrm{Co}^{2+}$ can replace $\mathrm{Ca}^{2+}$ in $\mathrm{Ca}-\mathrm{O}$ bonds on the cement particle surfaces and inside the hydration product. Furthermore, $\mathrm{Co}^{2+}$ does not change the crystal lattice structure of the hydration product.

\subsection{Long-Term Leaching Performance}

\section{Mine Location}

The metal ion concentrations in the underground mine water are shown in Table 2. In the north-western part of Zambia, the concentrations of the target heavy metals were higher than the corresponding international standards [36]. The concentrations of $\mathrm{Co}^{2+}, \mathrm{Ca}^{2+}$, and $\mathrm{As}^{5+}$ in the mine water were lower than the experimental and regulated values $[37,38]$. The CPB body has a considerable consolidation effect on the target metal ions. However, the $\mathrm{Zn}^{2+}$ and $\mathrm{Pb}^{2+}$ results shown in Table 2 require further study.

Table 2. Heavy metal ion concentrations in the underground mine water $(\mathrm{mg} / \mathrm{L})$.

\begin{tabular}{cccccc}
\hline Sample & $\mathbf{C o}^{2+}$ & $\mathbf{Z n}^{2+}$ & $\mathbf{P b}^{2+}$ & $\mathbf{A s}^{\mathbf{5 +}}$ & $\mathbf{C d}^{\mathbf{2 +}}$ \\
\hline -116 m 1\# mine water & 0.0082 & 0.49 & 0.236 & 0.049 & $<0.001$ \\
-200 m 2\# mine water & 0.0078 & 0.36 & 0.168 & 0.045 & $<0.001$ \\
-264 m 3\# mine water & 0.0013 & 0.26 & 0.114 & 0.038 & $<0.001$ \\
$\begin{array}{c}\text { Regulated value } \\
\text { [Nachiyunde et al., 2013; 2013a] }\end{array}$ & 0.01 & 5 & 0.05 & 0.058 & 0.005 \\
$\begin{array}{c}\text { Background water } \\
\text { [Psutka et al., 2011] }\end{array}$ & 0.0066 & 0.0239 & 0.00042 & 0.58 & 0.00159 \\
\hline
\end{tabular}

The concentration of $\mathrm{Zn}^{2+}$ was also lower than the regulated value and decreased with mining depth. At a depth of $-116 \mathrm{~m}$, the $\mathrm{Zn}^{2+}$ concentration was $0.49 \mathrm{mg} / \mathrm{L}$, which decreased to $0.26 \mathrm{mg} / \mathrm{L}$ at $-264 \mathrm{~m}$. However, the concentration of $\mathrm{Zn}^{2+}$ in the mine water was still 10-20 times more than that of the background water, therefore, in the natural environment, $\mathrm{Zn}^{2+}$ poses a major challenge to the prevention and control of water pollution.

The concentration of $\mathrm{Pb}^{2+}$ in the mine water was $0.236 \mathrm{mg} / \mathrm{L}$ at a depth of $-116 \mathrm{~m}$, which decreased to $0.114 \mathrm{mg} / \mathrm{L}$ as the depth decreased to $-264 \mathrm{~m}$. The $\mathrm{Pb}^{2+}$ concentration was $2-4$ times more than the regulated value and 100-500 times more than that of the background water, however, despite the $\mathrm{Pb}^{2+}$ concentration decreasing significantly with mining depth, there remains a significant environmental containment risk. Considering their amphoteric nature, $\mathrm{Pb}^{2+}$-containing hydroxides encounter high-concentrations of $\mathrm{OH}^{-}$and generate soluble $\mathrm{Pb}(\mathrm{OH})^{3-}$, which accounts for the dissolution and re-precipitation of lead salts throughout the cement hydration process.

With regard to cement-based concrete and contaminated soil treatment, cement as a common heavy metal solidification reagent has been widely examined [39-42]. However, different from the materials in previous reports, CPB has a very low ratio of cementitious materials; the lattice structure produced by cement hydration only has an acceptable adsorption effect on a few specific ions and cannot effectively solidify $\mathrm{Pb}$ or $\mathrm{Zn}$ ions. Therefore, a solidifying agent for heavy metal ions should be added for future CPB operation. 


\section{Discussion}

\subsection{Porosity and Permeability of $C P B$}

\subsubsection{Porosity}

The NMR results showed that the porosity decreased from $46.07 \%$ to $40.88 \%$ over the course of $120 \mathrm{~d}$, as shown in Figure 10. The cement hydration process continued during soaking, and the new hydration product made the solidified matrix structure become denser. The hydration process increased the diffusion resistance.

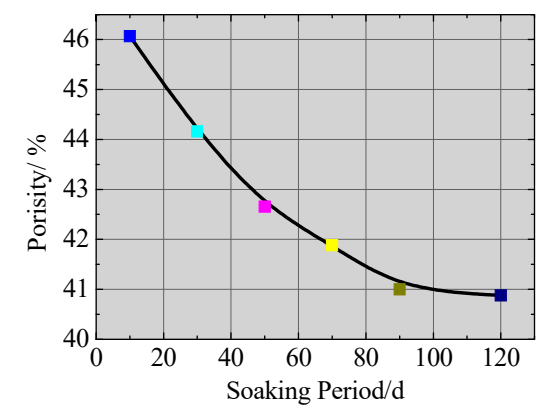

(a)

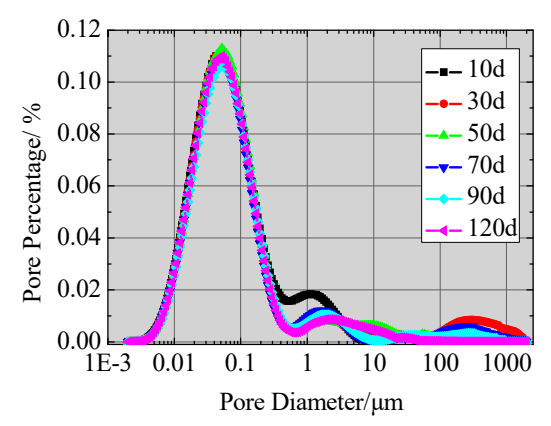

(b)

Figure 10. CPB mass (a) porosity vs. soaking period and (b) pore size distribution.

Based on the pore size distribution, $50 \%$ of the pores were smaller than $5.6 \mu \mathrm{m}$ and $80 \%$ were smaller than $13.81 \mu \mathrm{m}$. The pores with diameters less than $5 \mu \mathrm{m}$, were mostly isolated and not considerably affected by the concrete permeability performance. In contrast, the pores larger than $10 \mu \mathrm{m}$ were connected and thus had a significant influence on CPB permeability. The total porosity reached $100.3 \%$ of the final porosity at $90 \mathrm{~d}$, when the hydration process was complete.

\subsubsection{Permeability}

The permeability test showed that the permeability was proportional to the porosity. The permeability decreased from 0.8 to $0.5 \mathrm{~cm} / \mathrm{s}$ with soaking time, as the continuous hydration reaction blocked the seepage flow channels. The finer particles separated from the matrix under long-term soaking, which blocked the channels and increased the seepage resistance. The quantity, length, and diameter of the seepage channels decreased with soaking time. As shown in Figure 11, the quantity of main channels in the $1000 \mu \mathrm{m} \times 1000 \mu \mathrm{m} \times 1000 \mu \mathrm{m}$ cubic CPB blocks decreased from 10 to 4 over $120 \mathrm{~d}$, a drop of $60 \%$. The average streamlined length decreased from 0.8 to $0.3 \mathrm{~mm}$, a drop of $62.5 \%$, and the average channel diameter decreased from 1.1 to $0.5 \mu \mathrm{m}$, a drop of $54.5 \%$.

The simulation results showed that the permeability decreased from 1.2 to $0.7 \mathrm{~cm} / \mathrm{s}$, with immersion time. The hydraulic conductivity determined experimentally and via simulation were of the same order of magnitude; the difference was caused by the insufficient resolution of CT imaging. Parts of the narrow-hole channels which were less than the detection limit were ignored. 

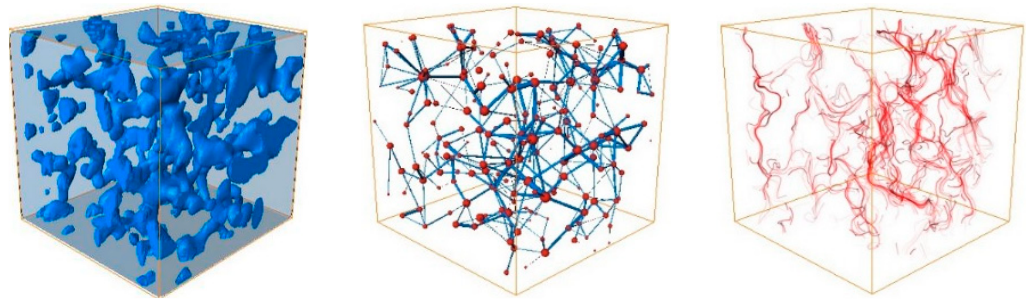

(a) 10 days leaching specimen
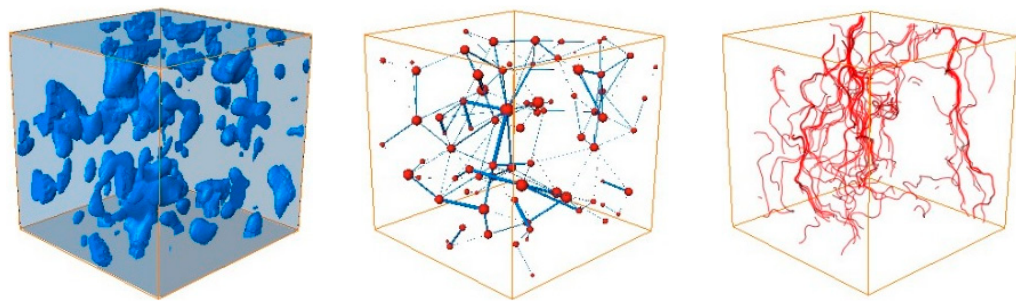

(b) 30 days leaching specimen
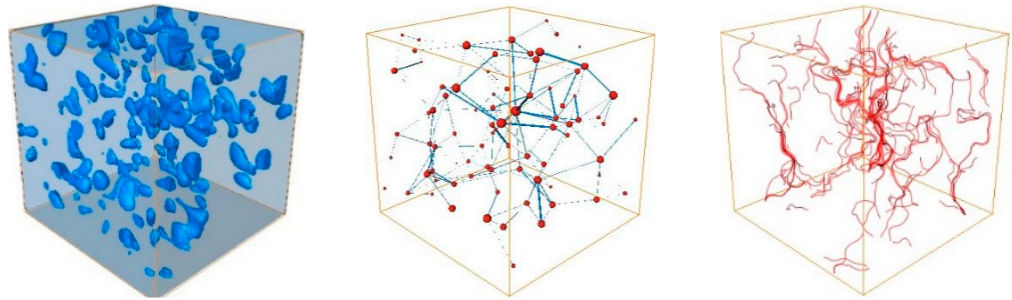

(c) 50 days leaching specimen
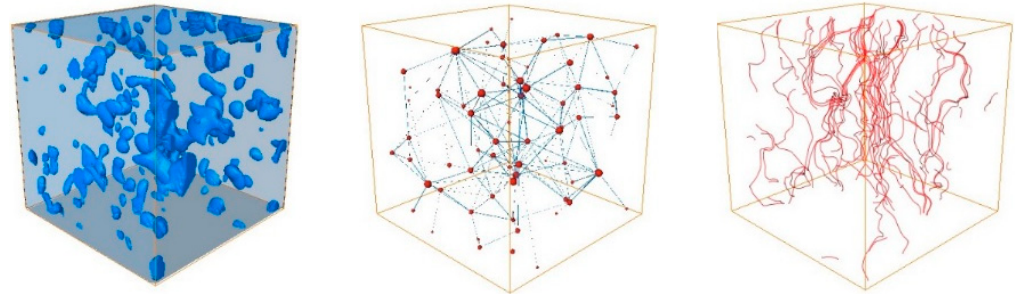

(d) 70 days leaching specimen

Figure 11. Three-dimensionally reconstructed visualised pores, pore network models, and seepage flow channel simulations.

It is difficult to discover seepage blind zones through macroscopic seepage experiments. Such zones significantly reduce the hydraulic conductivity, in which the geometrical characteristics of the pore network play an important role. Once the dominant flow is formed in the CPB, a seepage blind zone is inevitable. The solution cannot flow through these areas, and the solute transfer process can only occur by diffusion, resulting in low ion leaching rates around these areas.

\subsubsection{Solidification Mechanism}

Heavy metal ions are solidified into the cement hydration product by physical solidification, substitution, precipitation and isomorphic substitution, which prevent migration and diffusion into the environment, and thereby reduce the toxicity of the heavy metals. The C-S-H can hold or adsorb metal ions by ion replacement and surface electronegativity during the hydration process. When the radius of heavy metal ions is close to that of the ions in ettringite, $\mathrm{Al}^{3+}, \mathrm{Ca}^{2+}$ and $\mathrm{SO}_{4}{ }^{2-}$ can be replaced by the corresponding heavy metal ions, to form ettringite crystals.

As shown in Figure 12, the major product of C-S-H was a mixture of poorly crystallised particles, with different morphologies. It has been reported that there are four types of $\mathrm{C}-\mathrm{S}-\mathrm{H}$ defined according to morphology [43,44]: (1) fibrous (acicular crystal), (2) columnar reticular network [45], (3) equate 
grain morphology [46], and (4) inner product morphology. It is generally believed that the adsorption capacity of cement minerals to waste is ranked as follows: $\mathrm{C} 3 \mathrm{~A}>\mathrm{C} 3 \mathrm{~S}>\mathrm{C} 4 \mathrm{AF}>\mathrm{C} 2 \mathrm{~S}$. Heavy metal ions can also be adsorbed in other ways. An alkaline environment can cause heavy metal ions to form hydroxide precipitates, and physical encapsulation and chemical binding to ettringite can occur. The easier way is to adsorb or settle on the surface of tailing particles.

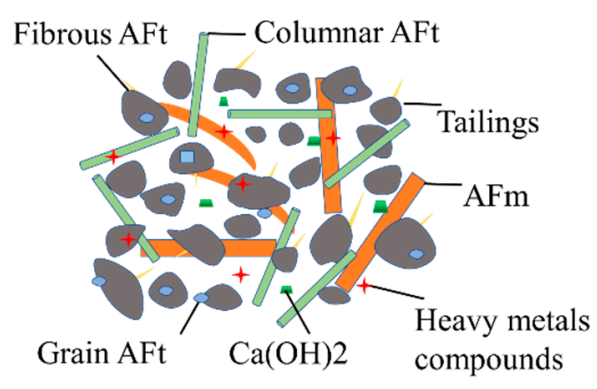

(a)

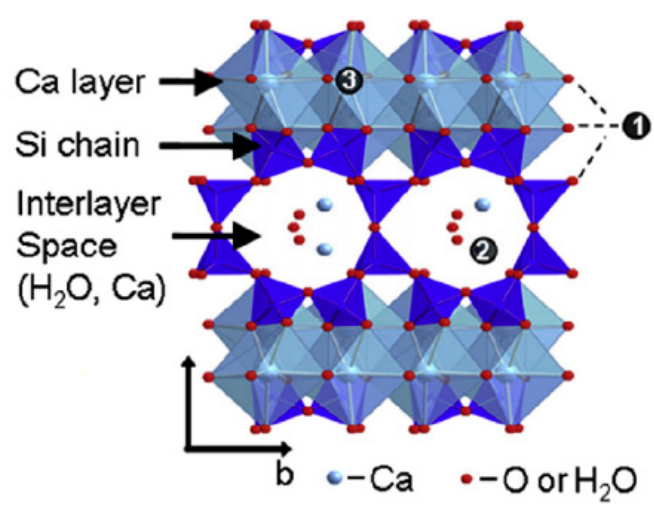

(b)

Figure 12. (a) Macro- and (b) molecular-scale illustrations of cement hydration adsorption mechanism for heavy metal ions.

\section{Conclusions}

Different from the traditional results of cement-based concrete materials analysis, the CPB material showed a significant selectivity in the adsorption of heavy metal ions. In the short term, CPB can adsorb $\mathrm{Co}^{2+}, \mathrm{Cd}^{2+}$ and $\mathrm{As}^{5+}$ effectively. Long-term sampling results showed that the contents of $\mathrm{Co}^{2+}$, $\mathrm{Cd}^{2+}$ and $\mathrm{As}^{5+}$ in mine water were lower than the experimental and regulated values. Within 120 days of $\mathrm{CPB}$ leaching, the $\mathrm{Co}^{2+}$ and $\mathrm{Cd}^{2+}$ concentrations were lower than the detection limit, whereas the $\mathrm{Zn}^{2+}, \mathrm{Pb}^{2+}$ and $\mathrm{As}^{5+}$ concentrations reached $0.49,0.08$, and $0.066 \mathrm{mg} / \mathrm{L}$, respectively.

In the long term, a large amount of $\mathrm{Zn}^{2+}$ and $\mathrm{Pb}^{2+}$ leached from the $\mathrm{CPB}$ materials. The content of $\mathrm{Zn}^{2+}$ was 10-20 times that of the background water, after eight years of immersion and leaching of the CPB mass. Most seriously, the $\mathrm{Pb}^{2+}$ concentration in the mine water was $0.114 \mathrm{mg} / \mathrm{L}$, which is 2-4 times the regulated value and 100-500 times that of the background water.

$\mathrm{CPB}$ technology has been considered attractive, but until now, it had not been well investigated whether it pollutes underground mine water. The results of this study indicate that controlling underground mine water pollution by the CPB mass should receive more attention, especially the possibility of adding a heavy metal ion solidification agent.

Author Contributions: Conceptualization: Y.Y., H.L.; methodology: Y.Y., H.J., Y.W.; formal analysis: T.Z., Y.W., H.L.; resources: T.Z., H.J.; data curation: Y.Y., H.J., Y.W.; writing一original draft preparation: Y.Y., H.J., Y.W., H.L.; writing-review and editing: T.Z.; visualization: H.J., H.L.; supervision: T.Z., H.L.; project administration: Y.Y.; funding acquisition: H.J., T.Z. All authors have read and agreed to the published version of the manuscript.

Funding: This research was funded by National Natural Science Foundation of China, grant number U1704241; 51704094 and Plan for Scientific Innovation Talent of Henan Province, grant numbers 194200510010.

Acknowledgments: This work was supported by the Nonferrous- Metals China Africa Mining Group Co Ltd.

Conflicts of Interest: The authors declare no conflict of interest. The funders had no role in the design of the study; in the collection, analyses, or interpretation of data, in the writing of the manuscript, or in the decision to publish the results.

\section{References}

1. Zhao, H.; Zhang, Y.; Zhang, X.; Qian, L.; Sun, M.; Yang, Y.; Qiu, G. The dissolution and passivation mechanism of chalcopyrite in bioleaching: An overview. Miner. Eng. 2019, 136, 140-154. [CrossRef] 
2. Yin, S.; Wang, L.; Wu, A.; Kabwe, E.; Chen, X.; Yan, R. Copper recycle from sulfide tailings using combined leaching of ammonia solution and alkaline bacteria. J. Clean. Prod. 2018, 189, 746-753. [CrossRef]

3. Sun, Q.; Li, B.; Tian, S.; Cai, C.; Xia, Y. Creep properties of geopolymer cemented coal gangue-fly ash backfill under dynamic disturbance. Constr. Build. Mater. 2018, 191, 644-654. [CrossRef]

4. Lu, H.; Zhang, S. Design of roof-contacted filling ratio and filling holes in the sublevel open stoping with the subsequent filling method. Int. J. Min. Miner. Eng. 2017, 8, 265-279. [CrossRef]

5. CNN. 2019. Available online: https://edition.cnn.com/2019/01/30/americas/brazil-dam-collapse-vale-miningregulations-intl/index.html (accessed on 3 December 2019).

6. Han, H.; Sun, W.; Hu, Y.; Jia, B.; Tang, H. Anglesite and silver recovery from jarosite residues through roasting and sulifidation-flotation in zinc hydrometallurgy. J. Hazard. Mater. 2014, 278, 49-54. [CrossRef]

7. Nhantumbo, C.M.C.; Larsson, R.; Juízo, D.; Larson, M. Key Issues for Water Quality Monitoring in the Zambezi River Basin in Mozambique in the Context of Mining Development. J. Water Resour. Prot. 2015, 7, 430. [CrossRef]

8. Onuaguluchi, O.; Eren, Ö. Reusing copper tailings in concrete: Corrosion performance and socioeconomic implications for the Lefke-Xeros area of Cyprus. J. Clean. Prod. 2016, 112, 420-429. [CrossRef]

9. Wu, B.; Li, X.G.; Ma, B.; Zhang, M. Solidification of heavy metals in ettringite and its stability research. In Proceedings of the 2nd International Conference on Microstructure-Related Durability of Cementitious Composites, Amsterdam, The Netherlands, 11-13 April 2012; pp. 1-9.

10. Yilmaz, E.; Belem, T.; Benzaazoua, M. Specimen size effect on strength behaviour of cemented paste backfills subjected to different placement conditions. Eng. Geol. 2015, 185, 52-62. [CrossRef]

11. Lu, H.; Wei, F.; Tang, J.; Giesy, J.P. Leaching of metals from cement under simulated environmental conditions. J. Environ. Manag. 2016, 169, 319-327. [CrossRef]

12. Fall, M.; Benzaazoua, M.; Saa, E.G. Mix proportioning of underground cemented tailings backfill. Tunn. Undergr. Space Technol. 2008, 23, 80-90. [CrossRef]

13. Sun, W.; Wang, H.; Hou, K. Control of waste rock-tailings pastes backfill for active mining subsidence areas. J. Clean. Prod. 2018, 171, 567-579. [CrossRef]

14. Chen, Q.; Zhang, Q.; Qi, C.; Fourie, A.; Xiao, C. Recycling phosphogypsum and construction demolition waste for cemented paste backfill and its environmental impact. J. Clean. Prod. 2018, 186, 418-429. [CrossRef]

15. Chen, Q.; Zhang, Q.; Wang, X.; Xiao, C.; Hu, Q. A hydraulic gradient model of paste-like crude tailings backfill slurry transported by a pipeline system. Environ. Earth. Sci. 2016, 75, 1099. [CrossRef]

16. Qi, C.; Fourie, A.; Chen, Q. Neural network and particle swarm optimization for predicting the unconfined compressive strength of cemented paste backfill. Constr. Build. Mater. 2018, 159, 473-478. [CrossRef]

17. Qi, C.; Fourie, A.; Chen, Q.; Zhang, Q. A strength prediction model using artificial intelligence for recycling waste tailings as cemented paste backfill. J. Clean. Prod. 2018, 183, 566-578. [CrossRef]

18. Moruzzi, R.B.; de Oliveira, A.L.; da Conceição, F.T.; Gregory, J.; Campos, L.C. Fractal dimension of large aggregates under different flocculation conditions. Sci. Total Environ. 2017, 609, 807-814. [CrossRef]

19. Rashed, M.N. Monitoring of contaminated toxic and heavy metals, from mine tailings through age accumulation, in soil and some wild plants at Southeast Egypt. J. Hazard. Mater. 2010, 178, 739-746. [CrossRef]

20. Sun, Q.; Tian, S.; Sun, Q.; Li, B.; Cai, C.; Xia, Y.; Mu, Q. Preparation and microstructure of fly ash geopolymer paste backfill material. J. Clean. Prod. 2019, 225, 376-390. [CrossRef]

21. Liu, L.; Zhu, C.; Qi, C.; Zhang, B.; Song, K.I. A microstructural hydration model for cemented paste backfill considering internal sulfate attacks. Constr. Build. Mater. 2019, 211, 99-108. [CrossRef]

22. Dell'Orso, M.; Mangialardi, T.; Paolini, A.E.; Piga, L. Evaluation of the leachability of heavy metals from cement-based materials. J. Hazard. Mater. 2012, 227, 1-8. [CrossRef]

23. Guo, B.; Liu, B.; Yang, J.; Zhang, S. The mechanisms of heavy metal immobilization by cementitious material treatments and thermal treatments: A review. J. Environ. Manag. 2017, 193, 410-422. [CrossRef] [PubMed]

24. Genesys, N.; Aouad, G.; Damidot, D. Managing trace elements in Portland cement-Part I: Interactions between cement paste and heavy metals added during mixing as soluble salts. Cem. Concr. Compos. 2010, 32, 563-570.

25. Giergiczny, Z.; Król, A. Immobilization of heavy metals ( $\mathrm{Pb}, \mathrm{Cu}, \mathrm{Cr}, \mathrm{Zn}, \mathrm{Cd}, \mathrm{Mn})$ in the mineral additions containing concrete composites. J. Hazard. Mater. 2008, 160, 247-255. [CrossRef] [PubMed] 
26. Wang, F.; Wang, H.; Al-Tabbaa, A. Leachability and heavy metal speciation of 17-year old stabilised/solidified contaminated site soils. J. Hazard. Mater. 2014, 278, 144-151. [CrossRef]

27. Wang, Y.; Han, F.; Mu, J. Solidification/stabilization mechanism of Pb (II), Cd (II), Mn (II) and Cr (III) in fly ash-based geopolymers. Constr. Build. Mater. 2018, 160, 818-827. [CrossRef]

28. Vollbrecht, A.; Brameshuber, W. Binding and leaching of trace elements in Portland cement pastes. Cem. Concr. Res. 2016, 79, 76-92. [CrossRef]

29. Li, C.; Wen, Q.; Hong, M.; Liang, Z.; Zhuang, Z.; Yu, Y. Heavy metals leaching in bricks made from lead and zinc mine tailings with varied chemical components. Constr. Build. Mater. 2017, 134, 443-451. [CrossRef]

30. Spacek, O.; Kříbek, B.; Mihaljevič, M.; Majer, V.; Veselovský, F.; Vencelides, Z.; Nyambe, I. Mining-related contamination of surface water and sediments of the Kafue River drainage system in the Copperbelt district, Zambia: An example of a high neutralization capacity system. J. Geochem. Explor. 2012, 112, 174-188.

31. Pettersson, U.T.; Ingri, J. The geochemistry of $\mathrm{Co}$ and $\mathrm{Cu}$ in the Kafue River as it drains the Copperbelt mining area, Zambia. Chem. Geol. 2001, 177, 399-414. [CrossRef]

32. Ntengwe, F.W.; Maseka, K.K. The impact of effuents containing zinc and nickel metals on stream and river water bodies: The case of Chambishi and Mwambashi streams in Zambia. Phys. Chem. Earth 2006, 31, 814-820. [CrossRef]

33. Environment Agency EA NEN 7375-2004. Leaching Characteristics of Moulded or Monolithic Building and Waste Materials. Determination of Leaching of Inorganic Components with the Diffusion Test; Based on a translation of the Netherlands Normalisation Institute Standard, Version 1.0; Environment Agency: Bristol, UK, 2004.

34. Yin, S.; Wu, A.; Hu, K.; Wang, Y.; Xue, Z. Visualization of flow behaviour during bioleaching of waste rock dumps under saturated and unsaturated conditions. Hydrometallurgy 2013, 133, 1-6. [CrossRef]

35. Jiao, H.; Wang, S.; Yang, Y.; Chen, X. Water recovery improvement by shearing of gravity-thickened tailings for cemented paste backfill. J. Clean. Prod. 2019. [CrossRef]

36. Nachiyunde, K.; Ikeda, H.; Tanaka, K.; Kozaki, D. Evaluation of portable water in five provinces of Zambia using a water pollution index. Afr. J. Environ. Sci. Technol. 2013, 7, 14-29.

37. Von der Heyden, C.J.; New, M.G. Groundwater pollution on the Zambian Copperbelt: Deciphering the source and the risk. Sci. Total Environ. 2004, 327, 17-30. [CrossRef] [PubMed]

38. Psutka, R.; Peletz, R.; Michelo, S.; Kelly, P.; Clasen, T. Assessing the microbiological performance and potential cost of boiling drinking water in urban Zambia. Environ. Sci. Technol. 2011, 45, 6095-6101. [CrossRef] [PubMed]

39. Agarwal, A.K. Leaching behaviour of fly ash used for adsorption of different metal ions from the aqueous solution after cement-based solidification. J. Mater. Eng. Struct. 2019, 5, 419-426.

40. Niu, M.; Li, G.; Wang, Y.; Li, Q.; Han, L.; Song, Z. Comparative study of immobilization and mechanical properties of sulfoaluminate cement and ordinary Portland cement with different heavy metals. Constr. Build. Mater. 2018, 193, 332-343. [CrossRef]

41. Cao, X.; Wang, W.; Ma, R.; Sun, S.; Lin, J. Solidification/stabilization of $\mathrm{Pb}^{2+}$ and $\mathrm{Zn}^{2+}$ in the sludge incineration residue-based magnesium potassium phosphate cement: Physical and chemical mechanisms and competition between coexisting ions. Environ. Pollut. 2019, 253, 171-180. [CrossRef]

42. Chen, Q.Y.; Tyrer, M.; Hills, C.D.; Yang, X.M.; Carey, P. Immobilisation of heavy metal in cement-based solidification/stabilisation: A review. Waste Manag. 2009, 29, 390-403. [CrossRef]

43. Clark, S.M.; Colas, B.; Kunz, M.; Speziale, S.; Monteiro, P.J. Effect of pressure on the crystal structure of ettringite. Cem. Concr. Res. 2008, 38, 19-26. [CrossRef]

44. Seryotkin, Y.V.; Sokol, E.V.; Kokh, S.N.; Sharygin, V.V. Natural bentorite- $\mathrm{Cr}^{3+}$ derivate of ettringite: Determination of crystal structure. Phys. Chem. Miner. 2019, 46, 553-570. [CrossRef]

45. Jiao, H.Z.; Wang, S.; Wu, A.; Shen, H.M.; Wang, J.D. Cementitious property of $\mathrm{NaAlO}_{2}$-activated Ge slag as cement supplement. Int. J. Miner. Metall. Mater. 2019, 26, 1594-1603. [CrossRef]

46. Jiao, H.; Wu, Y.; Chen, X.; Yang, Y. Flexural toughness of basalt fibre-reinforced shotcrete and industrial-scale testing. Adv. Mater. Sci. Eng. 2019. [CrossRef]

(C) 2020 by the authors. Licensee MDPI, Basel, Switzerland. This article is an open access article distributed under the terms and conditions of the Creative Commons Attribution (CC BY) license (http://creativecommons.org/licenses/by/4.0/). 